\title{
Judicial Impartiality and Independence of the Judiciary (Comparative Study)
}

\author{
Dr. AbdalrazakAlsheban \\ Faculty of Law/Cihan University / Sulaymaniyah
}

\begin{abstract}
For a trial to be fair, the judge or judges sitting on the case must be independent. All international human rights instruments refer to a fair trial by "an independent and impartial tribunal". The Human Rights Committee has repeatedly taken the view that the right to an independent and impartial tribunal is "an absolute right that may suffer no exception".

The principle of impartiality of the judge is one of the most important principles of judicial evidence, but one of the most important guarantees. Litigation, and is one of the most important principles limiting the judge's powers of proof in favor of the litigants.

The departure of the judge on the principle of neutrality is a waste of justice, which must be achieved by the judiciary, and this principle must be applied in all civil and criminal disputes, so as not to leave the judge from the judiciary to the Department of the opponent.

As justice is served through the judiciary that is made up of judges, it means that the judicial power is enforced only through the court of law represented by the judge, the sole carrier of all those powers.
\end{abstract}

Keywords:-Judicial, independence, authority, the judge, obligation, principle, partial, institutional, impartiality, impeachment, available, the jurisdiction.

\section{INTRODUCTION}

The principle of impartiality of the judge means that the judge is not prejudiced in his consideration of the case Parties to the dispute at the expense of the other party, and this is imposed on him ex officio. Under this principle, the judge is limited to forming his opinion and building his judgment on what the litigants give him. Evidence in accordance with the law, and shall adjudicate in the case brought against him according to what he concluded during his assessment Of the evidence submitted and as provided by law.

The philosophy of the idea of the independence and impartiality of the judge is that the judge, when adjudicated in the dispute before him, represents justice between the adversaries and the view of the group.

The right to a fair trial requires judges to be impartial. The right to be tried by an impartial tribunal implies that judges (or jurors) have no interest or stake in a particular case and do not hold pre-formed opinions about it or the parties. Cases must only be decided "on the basis of facts and in accordance with the law, without any restriction". To this end, the State, other institutions and private parties have an obligation to refrain from putting pressure on or inducing judges to rule in a certain way and judges have a correlative duty to conduct themselves impartially. The UN Basic Principles spell out this requirement: "[...] judges shall always conduct themselves in such a manner as to preserve the dignity of their office and the impartiality and independence of the judiciary". The Council of Europe has reiterated this principle, by saying that "Judges should have unfettered freedom to decide cases impartially, in accordance with their conscience and their interpretation of the facts, and in pursuance of the prevailing rules of the law" (International Commission of Jurists. 2007: 27).

\section{JUDICIAL IMPARTIALITY}

In granting judges independence, it is extremely important that their judicial authority be exercised in an impartial manner. Judicial independence brings with it the responsibility to administer the law impartially. Judicial impartiality is a fundamental component of justice. Judges are expected to be impartial arbiters so those legal disputes are decided according to the law free from the influence of bias or prejudice, or political pressure. The principle of judicial impartiality is dictated by statutory and common law, is required by the Code of Judicial Conduct, and is essential to due process of law. The Code of Judicial Conduct requires a judge to be disqualified from presiding over any proceeding in which the judge's impartiality might reasonably be questioned. This means that judges are disqualified from presiding over cases not only when they are in fact partial to one side or the other, but also when there is an appearance of partiality to the reasonable observer. Hence, judges are expected to avoid not only actual partiality, but the appearance of it as well, because the 
appearance of a judge who is not impartial diminishes public confidence in the judiciary and degrades the justice system (Sharman. J.1996:15)

\section{AN INDEPENDENT JUDICIARY}

An independent judiciary is anindispensable requisite for a free society under the rule of law. What exactly is meant by the concept of judicial independence? It is a concept that suggests that judges ought to be free from influence by the other branches of government, as well as from political, social, economic, or other influences. For the British, judicial independence meant that judges should be free from influence by the King or Parliament. For us in the United States, judicial independence means that judges should be free from influence by the executive or legislature. And in fact, judicial independence also means that judges should be free from influence by the people. Of course, judges are bound to follow the law, which the people may revise or amend through their representatives in the legislature. Naturally, judges should make their decisions according to the law, but otherwise should not be influenced by what the executive, the legislature, or even the people might think. Under this view, the ideal judge is a person who is learned in the law and who is independent, so that he or she will be guided in decision, making solely by legal knowledge and judicial experience (Sharman. J.1996:3)

\section{THE OBJECTIVE OF IMPARTIALITY OF JUDGES}

Much has been written about judicial independence both in its institutional and individual aspects. Judicial independence is sometimes mistakenly perceived as a privilege enjoyed by judges, whereas it is in fact a cornerstone of our system of government in a democratic society and a safeguard of the freedom and rights of the citizen under the rule of law. There are two aspects of this concept that are important for present purposes: Constitutional independence and independence in discharge of judicial duties (Australasian Institute of Judicial Administration Incorporated. 2007:4)

For a trial to be fair, the judge or judges sitting on the case must be independent. All international human rights instruments refer to a fair trial by "an independent and impartial tribunal". The Human Rights Committee has repeatedly taken the view that the right to an independent and impartial tribunal is "an absolute right that may suffer no exception". Even though a person's right to a fair trial may be respected in a particular case when a judge is independent, a State would be in breach of its international obligations if the judiciary were not an independent branch of power. Therefore, in this context, independence refers both to the individual judge as well as to the judiciary as a whole. International standards The UN Basic Principles on the Independence of the Judiciary lay out the requisite of independence in the first Principle:

"The independence of the judiciary shall be guaranteed by the State and enshrined in the Constitution or the law of the country. It is the duty of all governmental and other institutions to respect and observe the independence of the judiciary".

The Council of Europe's Recommendation on the Independence of Judges states that the independence of judges must be guaranteed by inserting specific provisions in constitutions or other legislation and that " $[t]$ he executive and legislative powers should ensure that judges are independent and that steps are not taken which could endanger the independence of judges".

The independence of the judiciary is also specifically recognised in other regional contexts, namely Africa and Asia-Pacific. In the case of Africa, it is worth highlighting the resolution on the respect and strengthening of the independence of the judiciary (International Commission of Jurists. 2007: 17).

\section{THE CREATION OF JUDICIAL INDEPENDENCE}

Of course, there is a very important question about judicial independence: How is itcreated and maintained? How does a nation or a stateestablish a judiciary that is in factindependent?

If we look to the judicial article of the federalConstitution, which is Article III, we seetwo significant devices that protect judicialindependence. First, Article III states that federaljudges shall hold their offices during good behavior and can only be removed fromoffice byimpeachment for the commission of high crimes or misdemeanors. Secondly, under Article III,the salaries of federal judges may not be lowered while they are in office. So, federal judges havevirtual life tenure, so long as they do notmisbehave, and their salaries are protected during thattenure. This is done in order to insulate themfrom attack by the executive branch or thelegislature.In addition to the federal judicial system, eachof the 50 states in the United States has itsown judiciary. The United States is afederated nation that has a federal government with its ownsovereign authority and that also is composed of 50 separate states, each of which has its ownsovereign authority and each of which has its own executive, legislature, and judiciary. All 50 ofthe state systems adhere to the doctrine of separation of powers and to the principle of anindependent judiciary. However, judicial independence is achieved differently in some of thestates than it is in the federal system (Sharman. J.1996:4) 


\section{THE RELATIONSHIP BETWEEN THE INDEPENDENCE AND IMPARTIALITY OF THE JUDICIARY}

Independence and impartiality are closely linked, and in many instances tribunal have dealt with them jointly. However, each concept has its own distinct meaning.

In general terms, "independence" refers to the autonomy of a given judge or tribunal to decide cases applying the law to the facts. This independence pertains to the judiciary as an institution (independence from other branches of power, referred to as "institutional independence) and to the particular judge (independence from other members of the judiciary, or "individual independence"). "Independence" requires that neither the judiciary nor the judges who compose it be subordinate to the other public powers. On the contrary, "impartiality" refers to the state of mind of a judge or tribunal towards a case and the parties to it. The Human Rights Committee has stated that in the context of article 14.1 of the ICCPR, "impartiality of the court implies that judges must not harbour preconceptions about the matter put before them, and that they must not act in ways that promote the interests of one of the parties". The notion of institutional independence is set out in the second sentence of Principle 1 of the UN Basic Principles, wherein the duty of all institutions to respect and observe that independence is guaranteed. This notion means that the judiciary has to be independent of the other branches of government, namely the executive and parliament, which, like all other State institutions, have a duty to respect and abide by the judgments and decisions of the judiciary. This constitutes a safeguard against disagreements over rulings by other institutions and their potential refusal to comply with them. Such independence as to decision-making is essential for upholding the rule of law and human rights. The European Court of Human Rights. has stated that a court must be independent both of the executive branch of government as well as of the parties to the proceedings (International Commission of Jurists. 2007: 21).

\section{THE DIFFERENCE BETWEEN JUDGE IMPARTIALITY AND IMPARTIALITY}

That the principle of impartiality of the judge does not mean non-bias, since each of the two principles a different meaning, as the non-bias differs from neutrality that prejudice means the judge standing by one of the adversaries and the preference of the other, contrary to the principle of equity and objectivity and equality of liabilities. As for impartiality, the judge stands between the dversaries and the position of the judge, so that his position is negative. His role is limited to assessing what they submit in the ways specified by the law from the evidence in the case.( Al Saadi. M. 2009: 14)

\section{THE IMPARTIALITY OF THE JUDGE}

In determining the existence of reasonable suspicion of a lack of impartiality on behalf of a judge, the stand-point of the accused is first considered. However, his/her view is not decisive, as such claims of impartiality have to be objectively sustained.

Principle number 3 of the Judges Charter in Europe expressly states that not only must the judge be impartial, he must be seen by all to be impartial. The European Court, in its turn, elevates the requirement of the appearance of impartiality to the rank of principle. This is necessary in order to not undermine the trust of the public (and, in criminal matters, the trust of the accused above anything else) that a court of law is supposed to inspire in any democratic society. The Court attached great importance to the English adagio, "justice must not only be done, it must be seen to be done." The result is that the manner, attitude, and manifestations of a judge hearing a case must be of a nature to show the parties that he/she does not intend to favour or disfavour either. It is therefore explicitly maintained that "the court must be and must appear to be independent and impartial." The consequence is that the system of "faceless tribunals" (judges wearing face masks to remain anonymous for anti-terrorist rationales) fails to guarantee the needed appearance of independence and impartiality (Danilet. C. 2010:18).

\section{JUSTIFICATION OF THE PRINCIPLE OF IMPARTIALITY OF THE JUDGE}

That the work of the judge focused mainly on how to apply the law properly, and this requires two basic processes: The first is to scrutinize the facts of the dispute before it for the purpose of verifying what has actually been issued by the parties to the dispute.

The second is the statement of the rule of law in relation to the facts and the ruling in the dispute.

The judge, who undertakes the first process, must not be aware of the facts of the dispute in advance. The litigants must prove these facts in accordance with the methods determined by law in this regard, and after that the judge must have his opinion in the light of what the stakeholders prove. Convinced of it is without the knowledge of individuals by it.( Omar. F. 1999)

\section{- The impartiality of the judge does not mean not making judgments}

It is impossible to require a judge who has had pre-trial contact with the contents of a case not to make an opinion on how he would probably rule on the case. However, based on the aforementioned situations, impartiality 
does not prohibit a judge from forming an opinion; it only prohibits a determination not to change it (in which case the hearings would become pointless). The judge must remain open to receiving new facts, arguments and interpretations. (Danilet. C. 2010:19)On the assumption that judicial decision making is not mechanical and thatjudges rely on considerations other than the plain meaning of statutory texts and (in common law systems) a narrow reading of the holdings of precedent cases, how can we formulate a test for impartiality that differentiates between permissible and impermissible grounds for judicial decisions (W. B. Wendel. 2008: 310).

\section{- The impartiality of the judge is the embodiment of the principle of separation of powers}

The principle of an independent judiciary derives from the basic principles of the rule of law, in particular the principle of separation of powers. The Human Rights Committee has said that the principle of legality and the rule of law are inherent in the ICCPR.56 The Inter-American Court of Human Rights has also stressed that "there exists an inseparable bond between the principle of legality, democratic institutions and the rule of law". According to this principle, the executive, the legislature and the judiciary constitute three separate and independent branches of government. Different organs of the State have exclusive and specific responsibilities. By virtue of this separation, it is not permissible for any branch of power to interfere into the others' sphere (International Commission of Jurists. 2007: 18). It is appropriate for a judge to make a submission or give evidence at such an inquiry if care is taken to avoid confrontation or the discussion of matters of a political rather than a legal nature, but prior consultation with the head of the jurisdiction is desirable. Again, the expertise or experience of a judge can be of great assistance in the examination of issues relating to legal or procedural matters. As long as discretion is exercised, this should not detract from the independence of the judiciary from the legislative and executive branches of government (Australasian Institute of Judicial Administration Incorporated. 2007:22).

\section{INDEPENDENCE IN ADMINISTRATIVE MATTERS}

According to the IBA Standards, judicial matters are exclusively within the responsibility of the Judiciary, both in central judicial administration and in court level judicial administration. The central responsibility for judicial administration shall preferably be vested in the Judiciary or jointly in the Judiciary and the Executive.

Article 14 of the Basic Principles on the Independence of the Judiciary stipulates that "the assignment of cases to judges within the court to which they belong is an internal matter of judicial administration." In addition, Principle 1, point 2, letters e) and f) in Recommendation no. R (94) of the Committee of Ministers of the Council of Europe states that, "the distribution of cases should not be influenced by the wishes of any party to a case or any person concerned with the results of the case. Such distribution may, for instance, be made by drawing of lots or a system for automatic distribution according to alphabetic order or some similar system. A case should not be withdrawn from a particular judge without valid reasons, such as cases of serious illness or conflict of interest. Any such reasons and the procedures for such withdrawal should be provided for by law and may not be influenced by any interest of the government or administration. A decision to withdraw a case from a judge should be taken by an authority which enjoys the same judicial independence as judges."

Examples of internal matters can also be found in article 36 of the Beijing Statement. The article states that the principal responsibility for court administration, including appointment, supervision and disciplinary control of administrative personnel and support staff must vest in the judiciary, or in a body in which the judiciary is represented and has an effective role. The head of the court may legitimately have supervisory powers to control judges on administrative matters(Danilet. C. 2010:6).

\section{THE PERSONAL INDEPENDENCE OF JUDGES}

As justice is served through the judiciary that is made up of judges, it means that the judicial power is enforced only through the court of law represented by the judge, the sole carrier of all those powers.

In the opinion of the law, the independence of the judge will negate the notion of a hierarchy or subordination. International principles expressly state that the judiciary shall decide matters before them impartially, on the basis of facts, and in accordance with the law, without any restrictions, improper influences, inducements, pressures, threats or interferences, direct or indirect, from any quarter or for any reason . The judge, as holder of judicial office, must be able to exercise judicial powers free from social, economic and political pressure, and independently from other judges and the administration of the judiciary. The independence of a court is appreciated by this point of view, both from the Executive branch and the parties, and from exterior powers such as the mass-media.(Danilet. C. 2010:7-8).

The impartiality of a court can be defined as the absence of bias, animosity or sympathy towards either of the parties. However, there are cases in which this bias will not be manifest but only apparent. That is the reason why the impartiality of courts must be examined from a subjective as well as an objective perspective. 
The European Court of Human Rights makes a distinction between "a subjective approach, that is endeavouring to ascertain the personal conviction of a given judge in a given case, and an objective approach, that is determining whether he offered guarantees sufficient to exclude any legitimate doubt in this respect". The first of these concepts is called subjective impartiality; the second is referred to as objective impartiality. A trial will be unfair not only if the judge is not impartial but also if he or she is not perceived to be impartial. The European Court of Human Rights has a long line of jurisprudence in which these two requirements of impartiality are defined. According to the Court, a judge or tribunal will only be impartial if it passes the subjective and objective tests. The subjective test "consists in seeking to determine the personal conviction of a particular judge in a given case". This entails that "no member of the tribunal should hold any personal prejudice or bias. Personal impartiality is presumed unless there is evidence to the contrary". The objective requirement of impartiality "consists in ascertaining whether the judge offered guarantees sufficient to exclude any legitimate doubt" as to his or her impartiality. Under the Court's jurisprudence, if either test fails, a trial will be deemed unfair (International Commission of Jurists. 2007: 28).

\section{MEANS OF PROVIDING INDEPENDENCE AND IMPARTIALITY TO JUDGES}

\section{- Irremovability of judges during office}

The strongest safeguard of the independence of judges is their irremovability. A judge holding office at a court may not in principle be moved by transfer, delegation, secondment elsewhere, even by way of promotion, without having freely consented thereto. Judges can be suspended or dismissed from office only under the law that regulates their statute.

The irremovabilityshould not be seen as a privilege of the judges, but rather as a safeguard for users of justice. That is why irremovability should also apply to how judges are appointed to the various chambers of the courthouses and to the allocation of cases and the possibility of recusing the judge. There is a rule that a case should not be withdrawn from a particular judge without valid reason, such as serious illness or conflict of interest.

The Council of Europe recognizes three exceptions to the principle of irremovability: 1) where transfer is provided for and has been pronounced by way of a disciplinary sanction; 2) when a lawful alteration of the court system occurs; and, 3) in the case of a temporary assignment to reinforce a neighbouring court, the maximum duration of such assignment being strictly limited by the statute. Point 29 of the Beijing Statement says the abolition of the court of which a judge is a member must not be accepted as a reason or an occasion for the removal of a judge. Where a court is abolished or restructured, all existing members of the court must be reappointed to its replacement or appointed to another judicial office of equivalent status and tenure. Members of the court for whom no alternative position can be foundmustbefully compensated (Danilet. C. 2010:10).

\section{- Give the judge the right to step down in certain cases}

The concept of impartiality creates a correlative duty for judges to step down from cases in which they think they will not be able to impart justice impartially or when their actual impartiality may be compromised. In these cases, they should not expect the parties to a case to challenge their impartiality but should excuse themselves and abstain from sitting in the case. The Bangalore Principles of Judicial Conduct, which were adopted by the Judicial Group on Strengthening Judicial Integrity and noted by the UN Commission on Human Rights, include impartiality as one of the fundamental values inherent in the judicial function. Principle 2.5 provides detailed guidelines as to the cases in which judges should disqualify themselves from a case: - A judge shall disqualify himself or herself from participating in any proceedings in which the judge is unable to decide the matter impartially or in which it may appear to a reasonable observer that the judge is unable to decide the matter impartially.Such proceedings include, but are not limited to, instances where - the judge has actual bias or prejudice concerning a party or personal knowledge of disputed evidentiary facts concerning the proceedings; - the judge previously served as a lawyer or was a material witness in the matter in controversy; or - the judge, or a member of the judge's family, has an economic interest in the outcome of the matter in controversy: Provided that disqualification of a judge shall not be required if no other tribunal can be constituted to deal with the case or, because of urgent circumstances, failure to act could lead to a serious miscarriage of justice (International Commission of Jurists. 2007: 30).

Judges should be aware that the majority of complaints to the Judicial Commission of New South Wales involve allegations of bias against a party, or failure to give a fair hearing. For the most part such complaints have not been sustained, but they indicate the need for care to avoid them.

The guiding principles are: Whether an appearance of bias or a possible conflict of interest is sufficient to disqualify a judge from hearing a case is to be judged by the perception of a reasonable well-informed observer. Disqualification on trivial grounds creates an unnecessary burden on colleagues, parties and their legal advisers; The parties should always be informed by the judge of facts which might reasonably give rise to a 
perception of bias or conflict of interest but the judge must himself or herself make the decision whether it is appropriate to sit (Australasian Institute of Judicial Administration Incorporated. 2007:10)

\section{- The judge may not be employed in another job}

Article 7 in the Universal Charter of the Judge holds that "the judge must not carry out any other function, whether public or private, paid or unpaid, that is not fully compatible with the duties and status of a judge. The judge must not be subject to outside appointments without his or her consent."

The IBA Standards list the activities that are incompatible with the judicial office: judges may not serve in executive functions, such as ministers of the govemment, nor may they serve as members of the Legislature or of municipal councils, unless by long historical traditions these functions are combined; judges may serve as chairmen of committees of inquiry in cases where the process requires skill of fact-finding and evidence-taking; judges shall not hold positions in political parties; a judge, other than a temporary judge, may not practice law during his/her term of office; a judge should refrain from business activities, except his/her personal investments, or ownership of property (Danilet. C. 2010:20-21).

The judiciary needs adequate resources to discharge its functions appropriately. As one of the three branches of power, the judiciary receives its resources from the national budget, which, in turn, is usually determined by either the legislature or the executive. It is essential that those outlining and approving the State budget take the needs of the judiciary into consideration. Inadequate resources may render the judiciary vulnerable to corruption, which could result in a weakening of its independence and impartiality. In determining the resources allocated to the judiciary, consultations must be held with judges or groups of judges. Another factor that undermines judicial independence and impartiality is the lack of participation of the judiciary in the elaboration of its budget. This is due to the fact that one of the most common and effective ways of controlling any institution is by restricting its finances. Inasmuch as other branches of power or State institutions wield an important influence in the allocation and administration of those resources given to the judiciary, there is a real possibility of influencing the outcomes of particularly sensitive cases, which would entail an attack on the independence of the judiciary. To this end, many States have created, within the judiciary, bodies in charge of administering judicial resources, thus reinforcing the autonomy of the judicial organ (International Commission of Jurists. 2007: 33).

\section{PROTECTION OF THE JUDGE}

The power of decision held by the judges can lead to unpopular decisions being made, which calls for a protection system to be in place for the judge.

Physically speaking, judges need to be provided with an adequate venue to conduct the proceedings in good conditions, and to be sure they are safe form any aggressive behaviour that may come from parties unhappy with their judgement, directed either at them or at their families. The security and physical protection of judges and of their families, according to Article 40 of the Beijing Statement, must at all times be ensured by the Executive authorities. Principie 3 point 2 in Recommendation no. R (94) foresees that "all necessary measures should be taken to ensure the safety of judges, such as ensuring the presence of security guards on court premises or providing police protection for judges who may become or are victims of serious threats."

Nevertheless, at a professional level, they need to be protected by a body independent from the Executive or Parliament. The Council of Europe recommends such a body within which at least one half of those who sit are judges elected by their peers following methods guaranteeing the widest representation of the judiciary. Every judge who considers that his or her rights under the statute, or more generally his or her independence, or the independence of the legal process, are threatened or ignored in any way, should be able to refer to such an independent authority. In turn, this authority should be empowered with effective means available in order to remedy the situation. The LAWASIA Organization maintains that such a body should be formed only of representatives of the highest jurisdiction and of the legal (Danilet. C. 2010:11).

\section{TRAINING AND EDUCATION}

Principle V.3.g of Recommendation no. R (94) 12 of the Council of Europe stipulates that judges should "undergo any necessary training in order to carry out their duties in an efficient and proper manner." States should take effective measures for that purpose as well as the necessary measures to make sure that large numbers of judges benefit from adequate training. The Cairo Statement stipulates in its third recommendation that all matters pertaining to the education and training programmes provided by the state should be subject to judicial supervision. Furthermore, the qualification programmesshall be focussed both on professional and judicial training and on individual development. The responsibility for adequate training is equally incumbent on the judges themselves and on their professional associations, according to Basic Principle 9.

The training should not only be in domestic law substantive and procedural but also international law, human rights, and educational programmes regarding the social context (Danilet. C. 2010:13-14). 


\section{APPEARANCE OF INDEPENDENCE}

One of the criteria considered in appreciating independence is the appearance. The case law of the Court of Strasbourg shows that it is necessary not only for justice to be made, but also for the conditions set by law in governing a fair trial appear to have been met. The appearance of independence from this point of view means the confidence that courts of justice are supposed to inspire in the public in a democratic society. The requirement is internationally enshrined through the adagio imported from the common law, according to which "justice must not only be done, it must be seen to be done".

In addressing suspicions concerning the possible lack of independent appearance, the point of view of the accused is considered. However, his/her claims must nevertheless be objectively justified.

Thus, it has been established that, as long as in a court of law there is a person reporting to one of the parties as position and tasks, users have a point in legitimately questioning that person's independence. This enshrines the need for a judge to be independent not only from the Executive and Parliament, but also from the parties. The same decision was passed in the case of a municipal police commission worker who in that capacity was viewed as an authority with jurisdictional competence. The worker had been in a senior position in the police before and was suspected of being called to fulfil such tasks again. The parties would always be inclined to see in that person a member of the police force who is part of a hierarchy and who would act in solidarity with his colleagues (Danilet. C. 2010:15).

\section{THE PERSONAL INTEGRITY OF THE JUDGE}

Personal (subjective) impartiality starts from the assumption that no member of the panel should have any prejudice or predilection. The judge must have no reason to favour or disfavoureither party. The subjective approach to determining a judge's impartiality would therefore mean determining the judge's private conviction during trial and in the adjudication of a particular case. The conduct favouring or disfavouring one of the parties may, for example, consist of making remarks suggesting that the judge is convinced of the guilt of the accused or of the judge's kinship with one of the parties.

The Court in Strasbourg ruled that a member of a jury in a court that had been overheard saying that he was a racist did not fulfil the condition of impartiality. Likewise, neither did a criminal chamber judge who had made a public statement suggesting the accused was guilty.

Recognising that subjective impartiality brings up the "interior forum" of the judge, the European Court of Human Rights recalled that the personal impartiality of a judge must be presumed until there is proof to the contrary. This applies to professional judges, members of a jury, and specialised professionals who participate alongside the judges in the adjudication of the matter (Danilet. C. 2010:17).

The fundamental value in judicial ethics is impartiality. This means that ajudge is duty-bound to decide cases on their merits, be open to persuasion, and not be influenced by improper considerations.' The paradigm case of unethical behavior by a judge is taking a bribe to decide a case in favor of one of the parties. This kind of corruption, which is fortunately rare in many developed countries, is also relatively uninteresting from an intellectual point of view. A more difficult case of failure of impartiality, conceptually speaking, involves a judge who relies on extra-legal factors as the basis for a judicial decision. Making sense of judicial ethics therefore requires a distinction between factors a judge may take into account when rendering a decision and those which are excluded from consideration. In American legal discourse, this distinction is often stated in terms of law vs. politics, where "politics" is used to mean any normative view that is not incorporated into the law (W. B. Wendel. 2008:305

\section{CONCLUSION}

Judicial independence is critical to the maintenance of the rule of law. An independent judiciary provides a balance and check upon the authority of the other branches of government and thereby prevents arbitrary government action. Whether elected or appointed, judges need to possess a certain degree of independence in order to foster the rule of law.

As justice is served through the judiciary that is made up of judges, it means that the judicial power is enforced only through the court of law represented by the judge, the sole carrier of all those powers. That the work of the judge focused mainly on how to apply the law properly, and this requires two basic processes:

The first is to scrutinize the facts of the dispute before it for the purpose of verifying what has actually been issued by the parties to the dispute. Independence and impartiality are closely linked, and in many instances tribunal have dealt with them jointly. However, each concept has its own distinct meaning.

In general terms, "independence" refers to the autonomy of a given judge or tribunal to decide cases applying the law to the facts. This independence pertains to the judiciary as an institution (independence from other branches of power, referred to as "institutional independence) and to the particular judge (independence from other members of the judiciary, or "individual independence"). 
That the principle of impartiality of the judge does not mean non-bias, since each of the two principles a different meaning, as the non-bias differs from neutrality that prejudice means the judge standing by one of the adversaries and the preference of the other, contrary to the principle of equity and objectivity and equality of liabilities.

\section{REFERENCES}

[1] Al Saadi. Mohamed Sabry. In the Explanation of the Civil Code, Dar al-Huda, Algeria, 2009.

[2] Australasian Institute of Judicial Administration Incorporated. GUIDE TO JUDICIAL CONDUCT , Australia,(Second Edition) 2007.

[3] CristiDanileţ, Independence and Impartiality of Justice - International Standards - .2010. http://www.cristidanilet.ro/docs/Independence_and_Impartiality_of_Justice\%20iun1010.doc.

[4] International Commission of Jurists. International Principles on the Independence and, Accountability of Judges, Lawyers and Prosecutors, Practitioners Guide No. 1, Switzerland, 2007.

[5] Omar. Faris Ali. The Principle of the impartiality of the civil judge, comparative study. Master Thesis, Faculty of Law, University of Mosul, Iraq, 1999.

[6] Sharman. Jeffrey. Judicial Ethics: Independence, Impartiality, and Integrity. Inter-American Development Bank, Sustainable Development Department, Governance and Civil Society Division,Washington. 1996.

[7] W. B. Wendel, Impartiality in Judicial Ethics: A Jurisprudential Analysis, 22 Notre Dame J.L. Ethics \& Pub. Pol'y 305 (2008). Available at: http://scholarship.law.nd.edu/ndjlepp/vol22/iss2/3 